\title{
Patterns of Regional Development in Serbia: A Multivariate Statistical Analysis
}

\author{
Čoček Ladislav ${ }^{A}$ \\ Received: December 2009| Revised: February 2010 | Accepted: February 2010
}

\begin{abstract}
The primary objective of this paper is to examine patterns of regional development in Serbia and to identify underlying geographical factors of these patterns. Principal component analysis is used to reveal the basic dimensions of regional differentiation. Its results are described in the context of findings from thematically similar research on Central European countries. An area's position in the national settlement system hierarchy has been identified as the strongest determinant of regional differentiation in Serbia. Other strong patterns seem to be connected with macro-geographical position. Success in economic development is most apparent in regions near the metropolitan area of Belgrade, and the general development level, along with a predisposition for agriculture, exhibits a strong north-south polarization. Specific attention is directed at demographic development, which is characterized by a west-east gradient. Central patterns of regional differentiation are similar to those uncovered in previous Central European research. Regional policy in Serbia should, therefore, try to learn from experience within this region to cope with processes and problems that are often quite similar.
\end{abstract}

Key words: Multivariate Analysis, Regional Development, Serbia

\section{Introduction}

In Central, Eastern and South-eastern Europe, post-communist transformation has been progressing at varying intensity with varying rates of success. Of the countries involved, Serbia was the last one to begin the transformation process and it has done so under difficult political and economic circumstances. While other post-communist countries were already knocking on the door of the European Union (EU), Serbia was struggling to emerge from democratic revolution and to apply elementary, market-oriented reforms. Its GDP p.c. was similar to that of Third World countries and its economy and politics were corrupt and disorganized. "It is hard to find a society that, in only ten years, could develop such a level of allround backwardness" (Mitrović, 2008, I35). One would expect that these specific conditions would lead to a pattern of regional development distinct from that of other post-communist countries.

This paper seeks to demonstrate, primarily on a theoretical basis originating from the Czech Republic, that, regardless of the specificity of the Serbian case, the basic factors determining regional development in most post-communist countries of Central Europe are also valid for Serbia. The underlying idea is that core geographical determinants are stable and, unless there is a strong force opposing them - such as communism's directive economic system or another autocracy, outcomes will be similar and manifest themselves extensively as soon as system changes allow them to do so. If this expectation holds true, it would strongly support a hypothesis describing the transferability of foreign experience with regional development into the Serbian environment. Such findings could have significant implications for regional policy practices.

This article attempts to offer an overview of basic factors of regional differentiation in Serbia in the broader context of Central and South-eastern Europe. First, contemporary concepts of regional development research in Central Europe and Serbia are evaluated and compared in a theoretical background section. The objective here is to present deficiencies in contemporary Serbian regional economic studies. Second, the methodological framework of the paper is summa-

A Department of Social Geography and Regional Development, Faculty of Science, Charles University in Prague, Albertov 6, 128 43 Praha 2, Czech Republic; e-mail: Icocek@gmail.com 
rized. The primary method employed is principal component analysis (PCA). The third section, entitled dimensions of regional development in Serbia, presents the results of the analysis and interprets them thoroughly. In the end, conclusions are drawn, including practical implications and regional perspectives resulting from the research.

\section{Theoretical Background}

Most research focusing on regional socioeconomic differentiation in Serbia, during the transformation period, has employed simple statistical methods or trivial comparison (Miletić, 2006; Mitrović, 2008; Rosić, 2004). More thorough attempts to unravel the complex patterns of regional development were often problem-oriented in nature (Jakopin, 2007), and in academic publications such attempts were rare (Grčić, Ratkaj, 2006; Radovanović, 2007). The problem of Serbia's striking regional differences is, nonetheless, widely acknowledged (Supić, 2007; Austrian Development Cooperation, 2006; Jakopin, et. al., 2003) and certainly calls for further investigation into its underlying causes, structural patterns and determinants.

The phenomenon of increasing regional economic disparities during post-communist transformation is not new. Evidence of this process has been gathered in most of the countries of Central, Eastern and South-eastern Europe (Blažek, I996; Enyedi, 2005; Gorzelak, I996; Hampl, 2007; Tomeš, 20oI; Tomeš, Hampl, I999). The regional pattern behind this observed development is not random. Dostál and Hampl (2002) identify a set of primary geographical factors of regional development in the Czech Republic that could be considered applicable for most post-communist countries. (I) The first of these factors is the hierarchical position of a region (its centre) in its national settlement system hierarchy, with special emphasis placed on the duality between metropolitan and non-metropolitan regions. (2) The macro-geographical position of an area, in terms of its distance from developed centres, is the second factor. This is derived, first, from the distance from the national capital and, second, from foreign centres of development. (3) The third factor is inherited economic specialization. In this context, economic specialization applies primarily to regions with a concentration of declining industrial branches and, therefore, it has generally negative consequences. To offer some confirmation, Barjak (200I), focusing on Poland and East Germany, identifies significant agglomerations as highly developed regions and areas peripheral to significant agglomerations, as well as former industrial regions, as problematic. As of yet, no study in
Serbia has attempted to verify the applicability of these theoretical presumptions. Therefore, this paper offers new explanatory insight into the regional differentiation of Serbia.

Nevertheless, certain factors must be interpreted with caution, with regard for the regional specifics of Serbia. For example, macro-geographical position must be carefully explained, making consideration for foreign centres of development, due to the fact that Serbia does not border any region, such as Bavaria or Lower Austria for the Czech Republic or Vienna for Slovakia and Hungary. Vuksanović, et. al. (2004), for example, provide some insight into cross-border economic relationships of Vojvodina. The west-east polarization of Central European countries is, in Serbia, traditionally replaced with a north-south gradient (Mihailovič, I990; Ocić, I998), but questions remain as to whether the regions of western Romania or southern Hungary, although currently more developed economically, could exert an influence similar to regions along the western border of the Czech Republic or Hungary. It is more accurate to assert that any north-south gradient in Serbia is a result of physical geography or historical reasons.

\section{Methodological Considerations}

For the purposes of this research concerning factors of regional differentiation in Serbia, the multivariate method known as principal component analysis (PCA) was selected. The basic idea of PCA is the "identification and elimination of redundancy in the information contained in variables or groups of variables. The aim is to replace a high number of preliminary characteristics and their relationships with a lower number of components" (Heřmanová, I99I, I7). The objective is reached by using matrix algebra and the resulting set of new uncorrelated variables, or components, is only one of an indefinite number of solutions. For a detailed description of the method, see Heřmanová (I99I) or Rummel (I970).

The PCA algorithm can create as many components as the initial number of variables, but with an appropriate dataset (the variables should be strongly correlated in a reasonably high number of cases) the first few should be capable of explaining most of the total variability in a dataset. The appropriate number of components to be extracted is usually defined by the eigenvalues of the correlation matrix of initial variables. In the case of this work, only components with eigenvalues (which represent the portion of total variability explained by a component) higher than one are used in the subsequent analyses. The results are usually further processed by rotating the space defined by components to reach a solution that is 
easier to explain. In this work, the rotation method used was Varimax with Kaiser Normalization.

PCA is used here to define the most important basic and specific dimensions of regional variability in Serbia. The territorial units used for analysis are districts (okruzi), which represent the meso-regional level. Although these districts are not typically organic regions, from the current Serbian statistical regionalization, they are the most appropriate for such analysis. The preliminary variables cover a broad spectrum of socio-economic indicators. Table I presents the variables in six divisions. The economic development level is represented by a set of four indicators. Development dynamics are evaluated using five indexes of predominantly economic indicators. The initial level of development is determined by two starting position indicators. Four indicators then focus on the structure of employment, followed by four demographic indicators and two additional factors.

Table 1. List of preliminary indicators for PCA

\begin{tabular}{|c|c|}
\hline \multicolumn{2}{|c|}{ ECONOMIC INDICATORS } \\
\hline 1 & National income p.c. 2004 \\
\hline 2 & Unemployment rate 2007 \\
\hline 3 & Economic aggregate p.c. 2007 \\
\hline 4 & Employment rate 2007 \\
\hline \multicolumn{2}{|c|}{ DEVELOPMENT INDICATORS } \\
\hline 5 & National income p.c. index 2004/1989 \\
\hline 6 & Employment rate index 2007/1989 \\
\hline 7 & Economic aggregate p.c. index 2007/2001 \\
\hline 8 & Unemployment rate index 2007/2001 \\
\hline 9 & $\begin{array}{l}\text { Employment in industry and mining index } \\
2007 / 1989\end{array}$ \\
\hline \multicolumn{2}{|c|}{ STARTING POSITION INDICATORS } \\
\hline 10 & Employment in industry and mining 1989 \\
\hline 11 & National income p.c. 1989 \\
\hline \multicolumn{2}{|c|}{ STRUCTURAL INDICATORS } \\
\hline 12 & $\begin{array}{l}\text { Employment in progressive sector [banking } \\
\text { and finance and real estate] } 2007\end{array}$ \\
\hline 13 & Employment in industry and mining 2007 \\
\hline 14 & Employment in agriculture 2007 \\
\hline 15 & Employment in industry and mining 2001 \\
\hline \multicolumn{2}{|c|}{ DEMOGRAPHIC INDICATORS } \\
\hline 16 & $\begin{array}{l}\text { Annual population change between } 1991 \text { and } \\
2002\end{array}$ \\
\hline 17 & Natural increase 2007 \\
\hline 18 & Ageing index 2002 \\
\hline 19 & Education index 2002 \\
\hline \multicolumn{2}{|c|}{ OTHER FACTORS } \\
\hline 20 & Population density 2002 \\
\hline 21 & Agricultural population share 2002 \\
\hline
\end{tabular}

One characteristic in particular, the economic aggregate (EA), does not occur frequently in statistics, but sometimes serves as a useful replacement for gross domestic product ( $\mathrm{Hampl}, 2005)$. EA is calculated as the product of the wages and number of employees in a region. In addition, this paper uses national income (NI) instead of the more frequently applied gross domestic product. These characteristics have a very similar purpose; they differ only in their method of calculation. NI and EA vary significantly at times, primarily due to over-employment and low productivity, in regions with companies undergoing restructuring; however, under ongoing transformation, the regional patterns of EA p.c. and NI p.c. are growing closer. All initial data were taken from publications of the Statistical Office of the Republic of Serbia.

The dataset shown in Figure I proved to be suitable for PCA, according to the Kaiser-MeyerOlkin Measure of Sampling Adequacy and Bartlett's Test of Sphericity. This means that, within the set of variables, there are groups that correlate significantly.

\section{Dimensions of Regional Development in Serbia}

The aim of the presented analysis is to identify the main dimensions of socio-economic regional differentiation in Serbia. This objective is reached with the extraction of an appropriate number of components from the initial dataset. The various components are then characterized with a component matrix describing the loadings of the initial variables. These loadings are the correlation coefficients between the components and each of the initial variables. The components can be interpreted as new axes in space defined by the original dataset - the coordinates of regions in this space are called component scores. A squared component loading describes the share of total variance in a specific variable explained by the particular component. The sum of all the variance shares from a set of variables that are described by a specific component, as shown in Table 2 for the initial and rotated solutions, represents the total variance explained by the component.

The optimal solution, according to above-mentioned criteria, that is presented in Table 2, extracts five components. After rotation, Component I explains nearly $29 \%$ of the total variability, Components 2 and 3 explain roughly I8\%, Component 4 less than $\mathrm{I} 3 \%$ and Component 5 slightly more than Io\% of the variability. Therefore, the first three can be interpreted as basic dimensions accounting for a significant portion of initial var- 
Table 2. Total variance explained by extracted components

\begin{tabular}{|c|c|c|c|c|c|c|c|c|c|}
\hline \multirow[t]{2}{*}{$\begin{array}{c}\text { Compo- } \\
\text { nent }\end{array}$} & \multicolumn{3}{|c|}{ Initial Eigenvalues } & \multicolumn{3}{|c|}{$\begin{array}{c}\text { Extraction Sums of Squared } \\
\text { Loadings }\end{array}$} & \multicolumn{3}{|c|}{$\begin{array}{c}\text { Rotation Sums of Squared } \\
\text { Loadings }\end{array}$} \\
\hline & Total & $\begin{array}{c}\% \text { of } \\
\text { Variance }\end{array}$ & $\begin{array}{l}\text { Cumu- } \\
\text { lative } \%\end{array}$ & Total & $\begin{array}{c}\% \text { of } \\
\text { Variance }\end{array}$ & $\begin{array}{l}\text { Cumu- } \\
\text { lative \% }\end{array}$ & Total & $\begin{array}{c}\% \text { of } \\
\text { Variance }\end{array}$ & $\begin{array}{l}\text { Cumu- } \\
\text { lative \% }\end{array}$ \\
\hline 1 & 9.042 & 43.058 & 43.058 & 9.042 & 43.058 & 43.058 & 6.030 & 28.716 & 28.716 \\
\hline 2 & 3.020 & 14.379 & 57.437 & 3.020 & 14.379 & 57.437 & 3.797 & 18.079 & 46.795 \\
\hline 3 & 2.361 & 11.242 & 68.680 & 2.361 & 11.242 & 68.680 & 3.614 & 17.209 & 64.004 \\
\hline 4 & 2.138 & 10.181 & 78.861 & 2.138 & 10.181 & 78.861 & 2.644 & 12.591 & 76.595 \\
\hline 5 & 1.675 & 7.977 & 86.838 & 1.675 & 7.977 & 86.838 & 2.151 & 10.243 & 86.838 \\
\hline
\end{tabular}

iance, while the other two dimensions specify the general pattern in certain special respects.

Table 3 presents the component loadings of the various components. Component I is characterized by the high loadings from employment in the progressive sector and the education index which, along with high loadings concerning the employment rate and population density and a low loading from agricultural population, imply that it should describe urban areas. Significant correlation with the most recent values of EA p.c. and NI p.c. shows that these areas also rank among the most economically developed. These underlying characteristics indicate that Component I is connected with the concept of the settlement system hierarchy, achieving its highest values in regions with important education centres, progressive services and a high degree of urbanization.

Developmental characteristics, including the employment rate, EA p.c. and NI p.c., have high loadings on Component 2, while recent unemployment has a low component loading. This implies that Component 2 characterizes development dynamics, due to the employment rate and EA p.c., which focus primarily on matters of employment; nonetheless, the NI p.c. loading shows that development of regional differences in production had a very similar pattern.

Component 3 is characterized by high loadings describing employment in agriculture and $\mathrm{NI}$ p.c. (both initial and final) and low loadings from the unemployment rate index and initial employment in industry and mining. This indicates that regions with high scores on this component are those with a high level of development that is not based on extensive industrialization, but rather on intensive agriculture or diversified industry at a lower scale. This setup proves to be accompanied by positive developments in the unemployment rate.

Component 4 shows a specific regional pattern of demographic behaviour in Serbia. It has very high negative loading from the ageing index and a significant positive loading from natural increase, while also correlating with the pop- ulation index between the last two censuses. The fifth component also shows a specific dimension of variability, most closely related to recent employment in industry and mining, but also exhibiting high loadings from other indicators of industrial employment including its development index.

Table 3: Rotated component matrix

\begin{tabular}{|c|c|c|c|c|c|}
\hline & \multicolumn{5}{|c|}{ Component } \\
\hline & 1 & 2 & 3 & 4 & 5 \\
\hline $\begin{array}{l}\text { Employment in progressive } \\
\text { sector } 2007\end{array}$ & .934 & & & & \\
\hline Education index 2002 & .917 & & & & \\
\hline Employment rate 2007 & .839 & & & & \\
\hline EA p.c. 2007 & .817 & & & & \\
\hline Population density 2002 & .800 & & & & \\
\hline $\begin{array}{l}\text { Agricultural population share } \\
2002\end{array}$ & -.754 & & & & \\
\hline $\begin{array}{l}\text { Employment rate index } \\
2007 / 1989\end{array}$ & & .924 & & & \\
\hline EA p.c. index 2007/2001 & & .862 & & & \\
\hline NI p.c. index 2004/1989 & & .673 & & & \\
\hline Unemployment rate 2007 & & -.601 & & & \\
\hline $\begin{array}{l}\text { Employment in agriculture } \\
2001\end{array}$ & & & .841 & & \\
\hline NI p.c. 1989 & & & .714 & & \\
\hline $\begin{array}{l}\text { Unemployment rate index } \\
\text { 2007/2001 }\end{array}$ & & & -.668 & & \\
\hline NI p.c. 2004 & .645 & & .656 & & \\
\hline $\begin{array}{l}\text { Employment in industry and } \\
\text { mining } 1989\end{array}$ & & & -.592 & & .535 \\
\hline Ageing index 2002 & & & & -.935 & \\
\hline Natural increase 2007 & & & & .925 & \\
\hline Population index 2002/1991 & & & & .676 & \\
\hline $\begin{array}{l}\text { Employment in industry and } \\
\text { mining } 2007\end{array}$ & & & & & .907 \\
\hline $\begin{array}{l}\text { Employment in industry and } \\
\text { mining index } 2007 / 1989\end{array}$ & & & & & .621 \\
\hline $\begin{array}{l}\text { Employment in industry and } \\
\text { mining } 2001\end{array}$ & & & & & .568 \\
\hline
\end{tabular}

Note: Loadings lower than .500 are not shown. 
This component proved to be less interpretable, in terms of its regional distribution, and, therefore, it will not be evaluated further.

Component I has high scores, especially in districts containing Serbia's main settlement centres, including Novi Sad, Belgrade, Kragujevac and Niš. The cartographic presentation in Figure I shows that these cities form a basic north-south axis in Serbia. The preceding evaluation of component loadings indicated that a high level of development, reasonable quality of human capital and an urban character are typical for Component I. This fits the description of regions well positioned in the national settlement system hierarchy. The visible pattern in Figure I confirms this assumption. High Component I scores are found particularly in the main metropolitan areas of Serbia and correspond with the position of regions in the national settlement system hierarchy.

Component 2, as presented in Figure 2, has notably high scores in the northern part of Central Serbia, especially in the Belgrade, Braničevo, Kolubara, Mačva, Podunavlje and Pomoravlje districts. Characteristics of these regions vary substantially - some are more industrial, others are, for the most part, rural, some have a clearly specialized industry while others are more differentiated. Most of these districts saw a sharp decline in economic output, during or before the crisis of the I990s, and, consequently, they grew from very low initial values, making their growth more pronounced. The resulting pattern cannot be interpreted as a universal development trend, but,

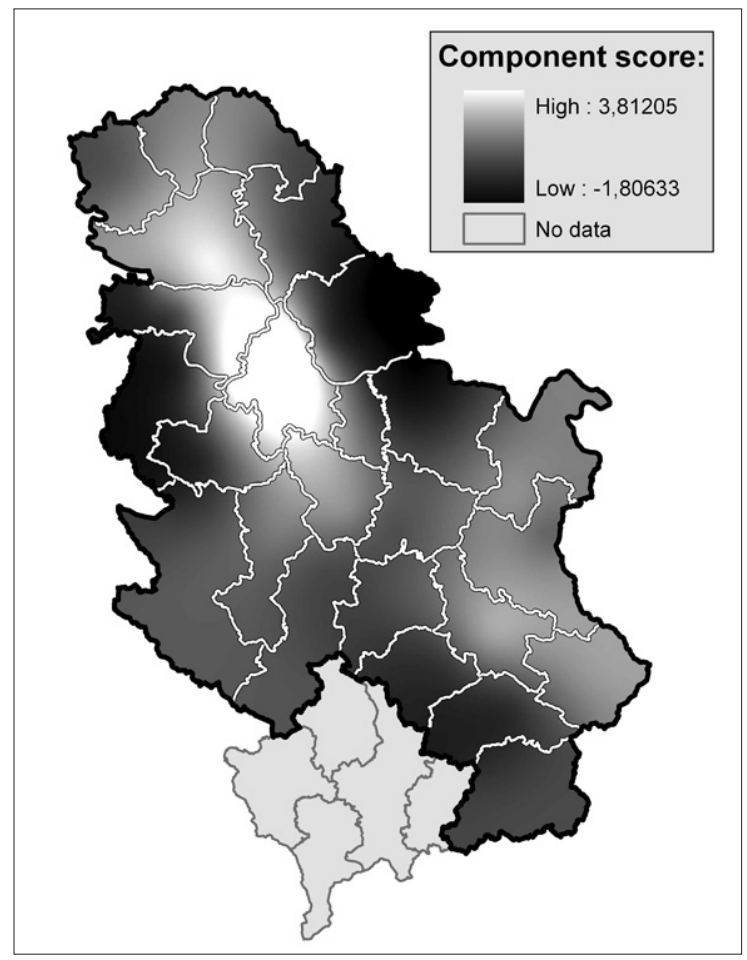

Figure 1: Component 1 scores particularly in terms of economic output and employment and in light of the very low initial level of these characteristics, the message of Figure 2 is clear: northern Central Serbia is coping with post-communist transformation and exhibits the best results so far. In addition to these districts, higher scores in Component 2 can also be identified in metropolitan regions, which predictably exploit the concentration of political or administrative power and qualitatively higher-level activities, such as tertiary education and quaternary economic activities to achieve higher economic growth rates.

Component 3 shows a clear north-south gradient. Its scores, as presented in Figure 3, are highest in Vojvodina and decrease gradually towards southern Central Serbia. Evaluation of Table 3 shows that there are multiple characteristics bound to this pattern. Most notable is employment in agriculture, which proved to be a "builtin stabilizer" during the I990s (Babić, I999) and, along with the positioning of the most strategic chemical industry in Vojvodina, it was behind the region's economic dominance, during the latter years of the totalitarian regime and continuing, to a lesser extent, to the present time. Moreover, the historical development of Vojvodina, especially concerning its agriculture and small scale industry, meant that the area required less "forced" socialist industrialization. "Naturally" occurring industrial activities, traditionally located in Vojvodina, would not lose ground as easily as the "artificially" implemented industry of southern Serbia

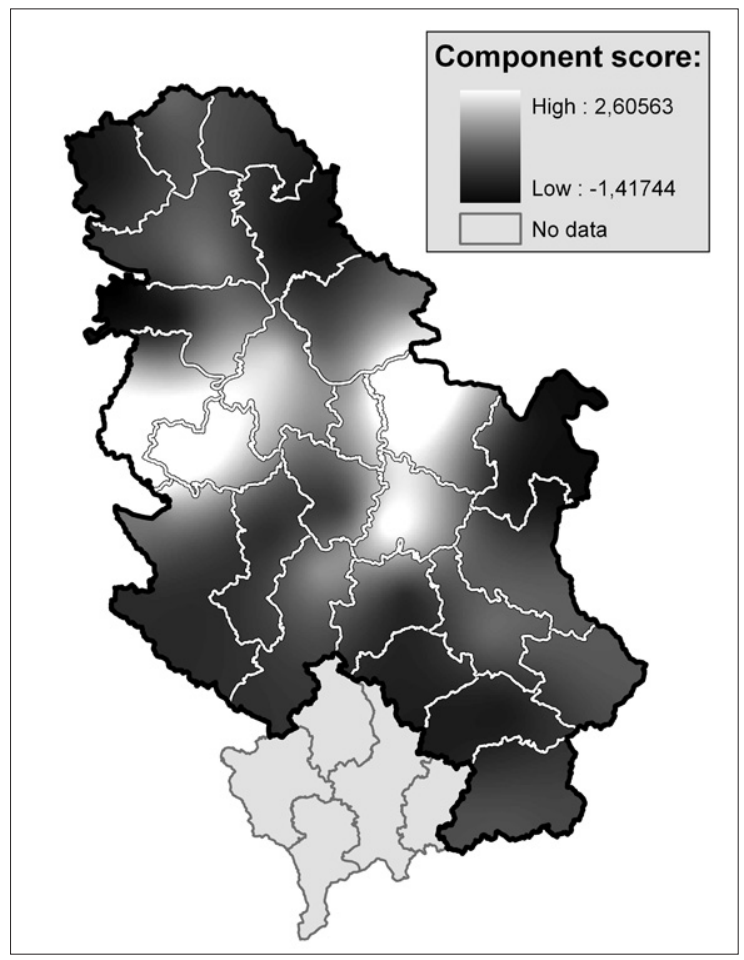

Figure 2: Component 2 scores 


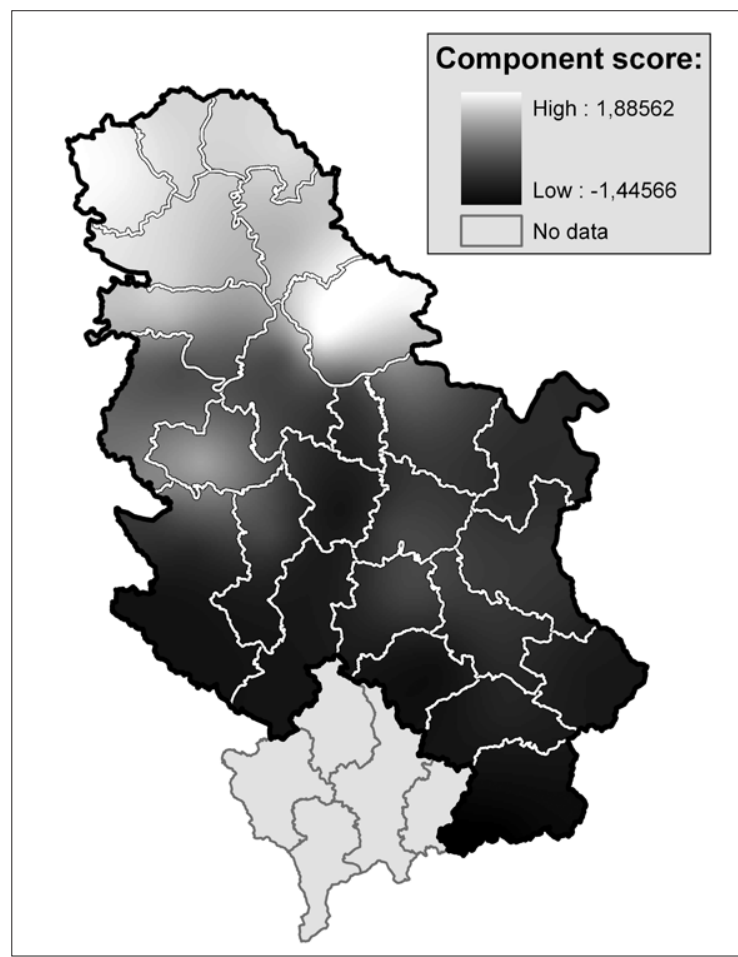

Figure 3: Component 3 scores

(for more on industrial distribution in Vojvodina, see Romelić, et. al., 2007; Romelić, Tomić, 2004). On the other hand, this higher level of immunity to the pronounced crisis of the I99os probably caused the moderate or lower growth rate in the subsequent period, as expressed in Component 2.

Component 4, based on demographic indicators, shows a specific pattern of regional development. As presented in Figure 4, its spatial differentiation is distinct from the other components. The gradient of Component 4 is oriented from west to east and, in Central Serbia southwest to northeast. There are multiple phenomena behind this pattern. I) The influx of refugees from Serb-inhabited areas in Bosnia-Herzegovina and Croatia during I990s was oriented primarily at regions along the western border of Serbia and the biggest cities. Therefore these areas did not suffer a major decline in population. 2) In the south and southeast of Serbia (Pčinja, Raška and Zlatibor districts), ethnic minorities with different demographic behaviour, Albanians and Bosniaks, are concentrated. Because of their very high natality rates, these regions experienced natural increase in population, which also expressed itself in general population developments. 3) Serbia was subject to an extensive population exodus during the I990s. In the areas mentioned above, this was countered with natural increase or immigration. However, in the districts of eastern Serbia, where the trend to emigrate is even more common (Filipović, 2007), there was no process to reduce the massive depopulation occurring. As a result,

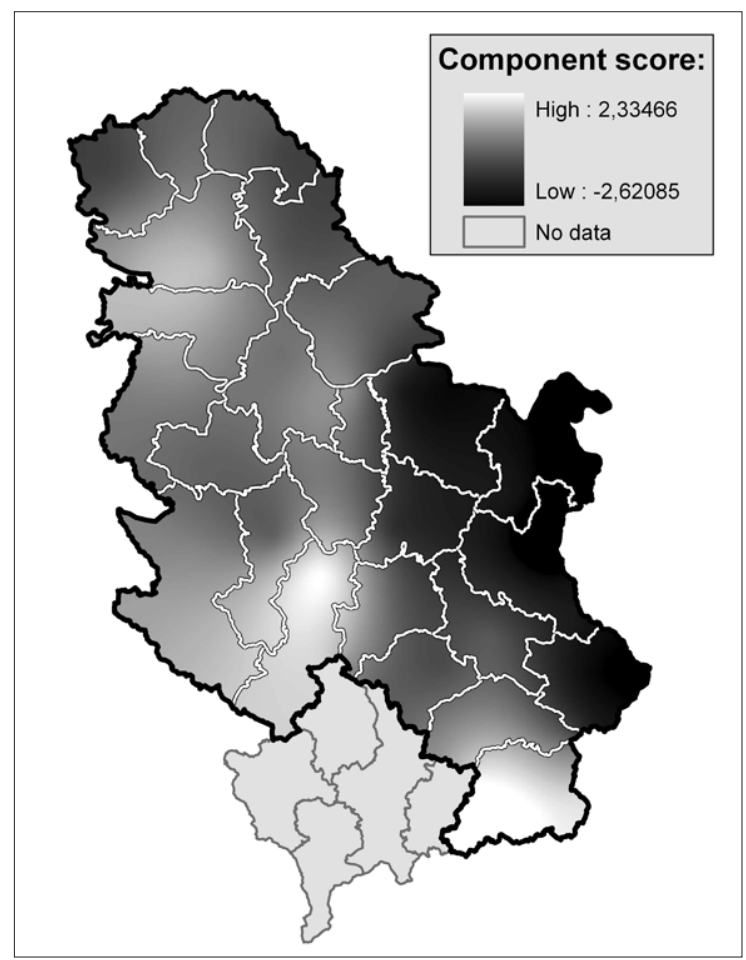

Figure 4: Component 4 scores

Component 4 scores are extremely unfavourable in the area.

\section{Conclusions}

From these dimensions (components) of regional differentiation, the first and the third components can be considered to be particularly similar to processes in Central European transformational countries. The first dimension is generally of universal validity (Hall, Hay, I980): an area's position in the national settlement system hierarchy determines the localization of tertiary education facilities or government offices and is associated with the density of interpersonal contacts. These factors lead to the placement of progressive services, banks and R \& D into major metropolitan areas, implying a higher level of economic development. The evolution of such patterns shaped the transformation period, although in some specific cases the switching of functions from manufacturing to services brought a temporary decline to certain regions. In Serbia, this pattern of inherited, unfavourable specialization is notable in the cases of the Nišava and Šumadija districts (with the cities Niš and Kragujevac), which could be expected to have higher Component I scores. On the other hand, in the case of Kragujevac, it could be argued that it is simply one step lower in the national settlement system hierarchy than the cities of Belgrade, Novi Sad and Niš and, therefore, that its score is reasonable.

Another pattern that could be generalized to describe most post-communist countries is gra- 
dient. In the case of Serbia, its direction is northsouth, while in Central European countries it is usually west-east. In both cases, however, it could be argued that the gradient moves from borders with more developed neighbours towards the European periphery. Although the spatial pattern is similar, the question remains as to whether its conditions differ or not. In Central European countries, the usual source of such a gradient is the proximity of developed cities and regions for the Czech Republic, this is Bavaria; for Slovakia and Hungary, Vienna; for Poland, it could be Berlin. More dynamic development in the western parts of these countries is supposed to be based on the diffusion of small and medium investment across state boundaries. What development pole, then, could Serbia be attached to? Could Budapest, Pécs or Timişoara play such a role? In the research presented in this paper, Component 3, characterized by its north-south gradient, is based primarily on employment in agriculture, and its correlation with NI p.c. declined between 1989 and 2004. This could raise doubts concerning the low progressivity and receding character of Serbia's north-south gradient. On the other hand, developments in the unemployment rate were positive during the post-communist transformation, which is a more valuable achievement, considering the obsolete manner of measuring $\mathrm{Nl}$, during the observed period. A detailed analysis of how strong the cross-border diffusion of development is would be worthwhile, but the effects would almost surely not reach the magnitude possible in Central Europe. The gradual pattern of regional differentiation in Serbia is probably caused by historical and cultural factors, rather than by neighbourhood effects. It is very likely that physical geography also plays a role in the development and persistence of the northsouth gradient, as agriculture is often regarded as "the safest and most profitable sector in Serbia” (Šabić, et. al., 2009, 27). Therefore, Vojvodina is provided with a competitive advantage against the rest of the country.

This gradient persists mainly in the duality of Vojvodina (with Belgrade) and Central Serbia. However, Component 2 also shows that, within Central Serbia, development is most dynamic in the northern part. This points to the evolution of a more fluid north-south gradient and also to the strengthening application of macro-geographical position, especially in terms of the distance from the national capital. The dynamic development of regions close to Belgrade is a reflection of its attractiveness, while districts further to the south tend to be neglected by investors.

Naturally, there are some disturbances among all the basic component patterns. Considering its tradition as an industrial centre, the city of Kragujevac and its surrounding Šumadija district could be expected to have the potential to achieve better economic results. However, the process of restructuring and privatizing Zastava, a company fundamental to the economic development of Kragujevac, was very complicated and its low productivity consistently hindered regional growth. Now that privatization of the major parts of the company is done, an improvement in the economic development of Šumadija can be expected. Another region with inherited unfavourable specialization is Bor in eastern Serbia - an area that was originally extremely dependent on one huge mining and metallurgic complex. Its export oriented production practically ceased to exist, during the I990s, and for such a giant enterprise to be eligible for privatization extensive restructuring (and fragmentation) was required.

There are some places with even poorer prospects - for example, the capacities of the textile industries in Raška and Jablanica districts practically disappeared and can hardly be expected to reappear. Throughout most of Serbia's peripheral south, socialistic industrialization created isolated activities with few connections to local resources and little embeddedness in the local economic environment (acknowledged as a fundamental problem of Yugoslav attempts at regional policy - see Mihajlović, I990; Ocić, I998). Such activities were sustainable only under the command economy of socialism, during (often even before) transformation, most of them went bankrupt. Now the problem is what strategy to select as a means of reviving economic activity in such peripheral areas - distance from poles of development, the poor quality of human capital and a prevailing rural character leave few choices. Tourism could contribute significantly to local development, but it would only have a major impact in a few of the most attractive places. Ecotourism, a frequently elicited option, could only serve as a complement to agricultural activities and light manufacturing. Emphasis must be placed on integral development and local initiative, even though this path to prosperity will be very long and difficult for peripheral areas.

The dualities present in Serbia will persist. The underdeveloped south will always present a contrast with the dynamically progressing north. Belgrade and its surroundings will prosper economically while the southern periphery struggles for basic functionality. At present, there is one more challenge affecting the entire country - the international economic crisis has impacted Serbia heavily. Successful national and regional development strategies in the aftermath of this crisis will be of crucial importance. The economic develop- 
ment of Serbia cannot be based solely on indigenous resources. The need for an inflow of foreign capital into the country - preferably in the form of foreign direct investment (FDI) - is ongoing. The prospects for privatization, the dominant form of FDI throughout the early years of Serbia's transformation (Hall, 2005), have decreased considerably; the primary objective should be the attraction of productive greenfield investments. In the case of Serbia, a considerable portion of this strategy has to be pursued through politics - the political climate in the country has been the main determinant of FDI inflow, during the first decade of the 2Ist century. The best guarantee for foreign investors would be EU candidate status; however, the key to its acquisition, the general consensus of EU member states concerning the need to continue the Stabilization and Association Process, is external by nature.

As confirmed by component analysis, regional differences in Serbia, along with their basic conditioning factors, share some common features with those of Central European countries. Basic characteristics - the strong domination of major metropolitan areas, borders with more developed countries on one side and less developed on the other, the decline of some industrial sectors and the rise of regional disparities after the abolition of the command economy - are shared by Serbia and contemporary, new EU member states. However, there is a huge difference in the magnitude of the crisis that followed the change from the old established socialist order. In Serbia an additional decade of dictatorship followed and, at the end of this period, NATO bombing destroyed what was left of the country's economy. National GDP p.c. was at the level of third world countries, the demographic composition of the population in some areas was truly catastrophic. Even after the democratic revolution, post-war conciliation consistently complicated Serbian external relationships, especially with the EU, thereby further hindering economic progress. However, there is still great potential for development, resulting from the country's strategic position and influence in the Western Balkans (Šabić, et. al., 2009), its moderate human resources and industrial heritage. Considering these similar patterns of regional differentiation, Serbia could employ and exploit experiences from Central European, post-socialist countries in regional and local development to, at least, limit the spread of regional disparities. Hopefully, with help from the EU, sustainable regional development will be pursued and reasonable results will be reached, before the rise of disparities leads to social unrest or political destabilization.

\section{References}

Adamović, J. 2002. Indicators of Socio-economic Development. Glasnik srpskog geografskog društva, 82,I, 9-I6. (in Serbian)

Adžić, S. 2008. Regional Policies and European Integration of Vojvodina. Prometej, Novi Sad, 249 pp. (in Serbian)

Austrian Development Cooperation 2006. Serbia Country Programme 2006-2008. Federal Austrian Ministry for Foreign Affairs, Vienna, 27 pp.

Babić, S. I999. The Political Economy of Adjustment to Sanctions: The Case of Serbia. Međunarodni odnosi, 2. Available at <http:// www.geocities.com/CapitolHill/Parliament/ 6682 /babic.html>.

Barjak, F. 200I. Regional Disparities in Transition Economies: A Typology for East Germany and Poland. Post-Communist Economies, I3,3, 289-3II.

Blažek, J. I996. Inter-regional Differences in the Czech Republic in Transformation Period. Geografie - Sborník ČGS, IOI,4, 265-277. (in Czech)

Dostál, P., Hampl, M. 2002. Regional development in the Czech Republic: Specific and general tendencies. In Domański, R. (ed.). Cities and regions in an enlarging European Union. Comittee for Space economy and Regional Planning, Polish Academy of Sciences, Warszaw, I29-I49.

Enyedi, G. 2005. Processes of Regional Development in Post-Socialist Hungary. In: Barta, G. (ed.). Hungarian Spaces and Places: Patterns of Transition. Hungarian Academy of Sciences Centre for Regional Studies, Pécs, 18-27.

Filipović, M. 2007. The Influence of Migration on Demographic Development of Eastern Serbia. In Aranđelović, Z. (ed.). Regional Development and Demographic Flows in the Countries of Southeastern Europe. Economic Faculty, Niš, 495-50I. (in Serbian)

Gorzelak, G. I996. The Regional Dimension of Transformation in Central Europe. Jessica Kingsley Publishers, London, 152 pp.

Grčić, M., Ratkaj, I. 2006. Structural Changes and Regional Differentiation of Industry in Serbia in the Period of Transition (I988-2005). Glasnik Srpskog geografskog društva, 86,2, 97-II2. (in Serbian)

Hall, D. 2005. Investment and Development in the Western Balkans. In Turnock, D. (ed.). Foreign Direct Investment and Regional Development in East Central Europe and the Soviet Union. Ashgate, Aldershot, I85-208.

Hall, P., Hay, D. I980. Growth Centre in the European Urban System. Keinemann, London, 278 pp.

Hampl, M. 2005. Geographical Organization of Society in the Czech Republic: Transforma- 
tional Processes and Their General Context. Charles University in Prague, Prague I47 pp. (in Czech)

Hampl, M. 2007. Regional Differentiation of Contemporary Socio-economic Development in the Czech Republic. Sociologický časopis, 43,5, 889-9Io. (in Czech)

Heřmanová, E. I991. Selected Multivariate Statistical Methods in Geography. Státní pedagogické nakladatelství, Prague, I33 pp. (in Czech)

Jakopin, E. (ed.) 2007: Regional Development Strategy of the Republic of Serbia. Republic Development Bureau, Belgrade, 2Io pp.

Jakopin, E., Radosavljević, S., Tontić, S. 2003. Regional Poverty of Serbia. In Aranđelović, Z. (ed.). Regional Development and Demographic Flows in the Balkan Countries. Economic Faculty, Niš, 9I-Ioo. (in Serbian)

Marsenić, D. 200I. Regional Development of Serbia in Transition. In Rosić, I., Marinković, R., Ilić, M., (eds.): Strategy of Development and Structural Changes of the Economy of Serbia in the Context of Transition. Economic Faculty, Kragujevac, 202-2I2. (in Serbian)

Mihailović, K. I990. Regional Reality of Yugoslavia. Ekonomika, Belgrade, 29I pp. (in Serbian with English summary)

Miletić, R. 2006. Selected Indicators of Uneven Regional Development of Serbia. Glasnik Srpskog geografskog društva, 86,I, I77-I9o. (in Serbian)

Mitrović, B. 2008. Transition and Regional Development in Serbia. In Aranđelović, Z. (ed.). Regional Development and Demographic Flows in the Countries of Southeastern Europe. Economic Faculty, Niš, I33-I39. (in Serbian)

Municipalities of Serbia I990, I997-2008. Statistical Office of the Republic of Serbia, Belgrade. (in Serbian)

Ocić, Č. 1998. The Regional Problem and the Break-Up of the State: The Case of Yugoslavia. Acta Slavica Iaponica, I6. Accessible at <http:// src-h.slav.hokudai.ac.jp/publictn/acta/r6/ caslav/caslav-I.html>

Privatization Agency of the Republic of Serbia 2005. Impact Assesment of Privatisation in Serbia. Privatization Agency Republic of Serbia, Belgrade, I87 pp.

Radovanović, V. 2007. Politics and Methods of Regional Development. Institute of Social Sciences, Belgrade, 384 pp. (in Serbian)

Romelić, J., Plavša, J., Stojanović, V., Lazić, L. 2007. Geographical Basis for the Distribution and
Organisation of Industry in Bačka. Geographica Pannonica, II, 43-47.

Romelić, J., Tomić, P. 2004. Geographical Bases of Industry Distribution in Vojvodinian Part of Banat. Geographica Pannonica, 8, 38-42.

Rosić, I. (ed.) 2004. Strategy of Regional Development in Serbia. Economic Faculty, Kragujevac, 299 pp. (in Serbian)

Rosić, I. 2007. Absence of Branch-regional and Balanced Development in Serbia. In Aranđelović, $Z$. (ed.). Regional Development and Demographic Flows in the Countries of Southeastern Europe. Economic Faculty, Niš, 25-35. (in Serbian)

Rummel, R. J. I970. Applied Factor Analysis. Northwestern University Press, Evaston, 592 pp.

Statistical Office of the Republic of Serbia. Accessible at <http://www.webrzs.statserb.sr.gov.yu>

Statistical Yearbook of Serbia 2003-2008. Statistical Office of the Republic of Serbia, Beograd.

Statistical Yearbook of Yugoslavia 1992-2002. Statistical Office of the Republic of Serbia, Beograd.

Supić, N. 2007. Regional Inequalities and European Integration of Serbia. In Aranđelović, Z. (ed.). Regional Development and Demographic Flows in the Countries of Southeastern Europe. Economic Faculty, Niš, 259-267. (in Serbian)

Šabić, D., Pavlović, M., Davidović, R. 2009: Serbia and Integration Processes in the Balkans. Geographica Pannonica, I3,I, 22-28.

Tomeš, J., Hampl, M. I999. The Development of Regional Differentiation in Eastern Central Europe Countries During the Transformational Era. In Hampl, M. (ed.). Geography of Societal Transformation in the Czech Republic. Charles University in Prague, Faculty of Science, Prague, I3I-I5I.

Tomeš, J. 200I. Current Tendencies of Regional Differentiation of Economy in Europe. In: Hampl, M. (ed.). Regional Development: Specifics of Czech Transformation, European Integration and General Theory. Charles University in Prague, Faculty of Science, Prague I69-I9o. (in Czech)

Tomić, P., Romelić, J. 2002. Transition and Transformation in Post-Socialistic Countries of Central and South-East Europe with a Particular View of FR Yugoslavia. Geographica Pannonica, $6,17-23$.

Vuksanović, G., Đurđev, B. S., Ivkov, A. 2004. The Province of Vojvodina in the Vicinity of EU Regions A General Comparison of Human Resources with the Emphasis on (Un)employment. Geographica Pannonica, 8, 29-32. 